\title{
Interannual variations in feeding frequencies and food quality of greater flamingo chicks (Phoenicopterus roseus): Evidence from plasma chemistry and effects on body condition
}

\author{
Juan A. Amat ${ }^{\mathrm{a},} \square$, Francisco Hortas $^{\mathrm{b}}$, Gonzalo M. Arroyo ${ }^{\mathrm{b}}$, Miguel A. Rendón ${ }^{\mathrm{a}}$, José M. Ramírez ${ }^{\mathrm{c}}$, \\ Manuel Rendón-Martos ${ }^{\mathrm{c}}$, Alejandro Pérez-Hurtado ${ }^{\mathrm{b}}$, Araceli Garrido ${ }^{\mathrm{c}}$ \\ a Estación Biológica de Doñana, C. S. I. C., Apartado 1056, E-41080 Sevilla, Spain \\ ${ }^{\text {b }}$ Departamento de Biolgía, Facultad de Ciencias del Mar, Universidad de Cádiz, Apartado 40, E-11510 Puerto Real, Spain \\ c Reserva Natural Laguna de Fuente de Piedra, Consejería de Medio Ambiente, Junta de Andalucía, Apartado 1, E-29520 Fuente de Piedra, Spain
}

\begin{abstract}
Greater flamingos in southern Spain foraged in areas distant from a breeding site, spending 4-6 days in foraging areas between successive visits to the colony to feed their chicks. During four years, we took blood samples from chicks to ascertain whether there were interannual variations in several blood parameters, indicative of food quality and feeding frequencies. When the chicks were captured, 20-31\% of them had their crops empty, indicating that not all chicks were fed daily. Additional evidence of variations in feeding frequencies was obtained from a principal component analysis (PCA) on plasma chemistry values, which also indicated that there were annual variations in the quality of food received by chicks. The association of cholesterol and glucose with some PC axes indicated that some chicks were experiencing fasting periods. Of all plasma metabolites considered, cholesterol was the best one to predict body condition. Greater flamingo chicks experiencing longer fasting intervals, as suggested by higher plasma levels of cholesterol, were in lower body condition.
\end{abstract}

Keywords: Chick; Cholesterol; Colonial waterbird; Fast; Greater flamingo; Interannual variations; Intermittent feeding; Nutritional condition; Plasma biochemistry

\section{Introduction}

Long-term fasting in endotherm vertebrates is characterized by three physiological phases, which are expressed in changes in body mass and in some biochemical plasma parameters (Le Maho et al., 1981; Robin et al., 1987, 1988; Alonso-Alvarez and Ferrer, 2001). During phase I there is a decrease in uric acid levels, but this metabolite increases during phase III as a result of muscle protein catabolism. During phase II stored lipids are used as an energy source. During prolonged fasting, corresponding to phase III, glucose levels drop (Le Maho et al., 1981; Robin et al., 1987). The duration of each one of these phases

\footnotetext{
Corresponding author. Tel.: +34 954232 340; fax: +34 954621125 . E-mail address: amat@ebd.csic.es (J.A. Amat).
}

varies across species (Hollmén et al., 2001; Alonso-Alvarez et al., 2003).

In marine birds, breeding adults of some species forage in areas very distant from breeding sites (N1000 km). Foraging trips of individual adults may last up to 14 days (e.g., Richdale, 1963; Chaurand and Weimerskirch, 1994; Hamer et al., 1997; Weimerskirch, 1998). These long periods mean that even though adults coordinate visits, chicks have to fast during some days between parental visits to provision them (e.g., Booth et al., 2000). The adults of some inland nesting colonial waterbirds may forage in areas located 130-400 km from nesting sites (Pyrovetsi, 1989; Rendón-Martos et al., 2000; Amat et al., 2005). Although foraging ranges in this last case are much shorter than in marine birds, inland nesting colonial waterbirds may still not visit daily their chicks to provision them. Indeed, greater flamingos (Phoenicopterus roseus) breeding in southern 
Spain spent 4-6 days in foraging areas between visits to the breeding lake to feed their chicks (Amat et al., 2005). Therefore, if chicks fast during some periods this may be expressed in the blood levels of some metabolites associated with fasting.

Flamingos use shallow wetlands in which variations in water levels are very dynamic (e.g., Rendón-Martos, 1996; Baldassarre and Arengo, 2000). These variations may occur both within as well as between years, and this may affect food availability. This in turn may affect the quality and/or quantity of food received by chicks, which may translate to differences in body condition of those chicks. Because nutrients may influence blood chemistry, some blood parameters may be used to assess the nutritional condition of individuals (Driver, 1981; Perry et al., 1986; Brown, 1996). Indeed, some plasma parameters, such as cholesterol, triglycerides, uric acid and total proteins, are frequently used to assess, as an indirect method, the body condition of individuals, as differences in these parameters may be related to changes in body masses and food quality (Jenni-Eiermann and Jenni, 1994, 1996; Dawson and Bortolotti, 1997; Ferrer and Dobado-Berrios, 1998; Ots et al., 1998; Alonso-Alvarez et al., 2002; Villegas et al., 2002; Quillfeldt et al., 2004). Besides giving information on the nutritional condition, some of these parameters, such as cholesterol, may provide also information on dehydration levels of individuals. It has been shown that dehydration during fasting increases plasma cholesterol (Campbell et al., 1994). Because young flamingos usually do not disperse from the natal site until late summer, they could suffer from dehydration if intervals between parental visits to the colony to feed them are long and ambient temperatures are high. This could be especially severe in wetlands that dry out during summer before chick dispersal, as in the lake where we conducted our study.

Most blood analyses of flamingos have been carried out on captive birds (Hawkey et al., 1984, 1985; Puerta et al., 1989; Peinado et al., 1992), and although there is some information on free ranging birds (Puerta et al., 1992; Mostaghni et al., 2005; Norambuena and Parada, 2005), this is on limited sample sizes and no control of fasting. The main emphasis of this previous work was to provide reference values with which to assess the health of populations. However, given the characteristics of flamingos' natural history, this information may be of limited use if the sampling process does not encompass multiple envi- ronmental conditions. Our paper has three main purposes. First, we wanted to provide evidence on whether greater flamingo chicks fast during the parental provisioning period. We predicted that if flamingo chicks fast, we should be able to detect variations in plasma levels of some metabolites similar to those reported for other birds during fasting, e.g. in uric acid and glucose, as the duration of the fasting period increases (see above). For this purpose we compared plasma metabolite levels of individuals with different crop profiles. The crop profiles may be used to identify those individuals that had been recently fed and those that were fasting (see below). The second purpose of our study was to document possible interannual variations in plasma chemistry values. We speculated that interannual variations in the foraging conditions experienced by adults may be expressed in the plasma chemistry. For this we compared intraspecific variations in plasma chemistry values among years. The third purpose was to assess whether some plasma biochemical parameters may serve to evaluate the body condition of individual chicks, especially in parameters that indicate variations in body mass (e. g., triglycerides) and/or in dehydration level (e.g., cholesterol) of individuals. Therefore for this third purpose we correlated individual plasma metabolite levels against a body condition index derived from body size-corrected body masses. Such data may be important for wetland managers, since it may help to interpret long-term physiological effects of the conditions experienced by chicks during the growing period on the population dynamics of a waterbird that may have an important effect on the functioning of wetlands (Amat et al., 2005; Rodríguez-Pérez and Green, 2006).

\section{Materials and methods}

The study was conducted at Fuente de Piedra lake in southern Spain $\left(36^{\circ} 06^{\prime} \mathrm{N}, 4^{\circ} 45^{\prime} \mathrm{W}\right)$. Greater flamingos (P. roseus, Phoenicopteridae) do not breed in this saline lake when water levels are low (Rendón-Martos and Johnson, 1996; Rendón et al., 2001). Starting in 1986, about $10 \%$ of the chicks in the crèche have been captured every year in a single day during a drive for ringing purposes. Body masses and wing, tarsus, and bill lengths have been recorded from ringed chicks. We used tarsus length as an indication of chick size, and estimated body condition as the residuals of an orthogonal

Table 1

Variations in plasma chemistry values (mean \pm S.D.) of greater flamingo chicks according to crop profile

\begin{tabular}{|c|c|c|c|c|c|c|}
\hline \multirow[t]{2}{*}{ Parameter } & \multicolumn{4}{|l|}{ Crop profile } & \multirow[b]{2}{*}{$\mathrm{H}$} & \multirow[b]{2}{*}{$\mathrm{P}$} \\
\hline & 0 & 1 & 2 & 3 & & \\
\hline Glucose (mmol/L) & $11.1 \pm 2.0(104)$ & $11.1 \pm 2.0(155)$ & $11.8 \pm 3.1(88)$ & $12.6 \pm 2.7(64)$ & 18.16 & b0.001 \\
\hline Cholesterol (mmol/L) & $7.5 \pm 1.9(104)$ & $7.2 \pm 2.2(156)$ & $7.1 \pm 1.9(87)$ & $7.1 \pm 2.1(64)$ & 3.04 & 0.386 \\
\hline Triglycerides (mmol/L) & $0.5 \pm 0.5(113)$ & $0.7 \pm 1.0(158)$ & $1.7 \pm 1.7(88)$ & $3.3 \pm 2.6(64)$ & 141.76 & b0.001 \\
\hline Uric acid $(\mu \mathrm{mol} / \mathrm{L})$ & $281.4 \pm 241.2(116)$ & $309.5 \pm 206.9(159)$ & $644.4 \pm 522.4(86)$ & $1087.2 \pm 630.7(67)$ & 151.79 & b 0.001 \\
\hline Total proteins (g/L) & $37.2 \pm 9.4(114)$ & $37.2 \pm 6.0(160)$ & $49.0 \pm 26.5(87)$ & $70.3 \pm 48.4(68)$ & 106.47 & b0.001 \\
\hline Alkaline phosphatase (U/L) & $1186.5 \pm 371.5(113)$ & $1195.8 \pm 399.0(157)$ & $1149.7 \pm 427.5(86)$ & $1253.7 \pm 1152.2(64)$ & 2.26 & 0.521 \\
\hline Calcium (mmol/L) & $2.8 \pm 1.1(101)$ & $2.7 \pm 0.4(146)$ & $3.2 \pm 1.7(85)$ & $4.8 \pm 3.1(58)$ & 66.25 & b 0.001 \\
\hline Phosphorus (mmol/L) & $1.7 \pm 0.7(96)$ & $1.8 \pm 0.6(139)$ & $2.3 \pm 0.9(84)$ & $2.9 \pm 1.2(56)$ & 82.81 & b0.001 \\
\hline Magnesium (mmol/L) & $0.6 \pm 0.3(98)$ & $0.6 \pm 0.2(140)$ & $0.7 \pm 0.3(84)$ & $0.9 \pm 0.4(56)$ & 42.12 & b0.001 \\
\hline
\end{tabular}

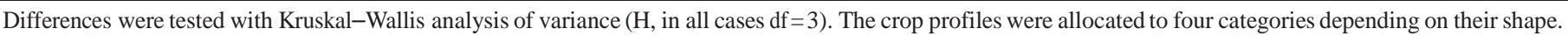

Sample sizes are in parentheses. 
regression of log-transformed body masses on log-transformed tarsus lengths (Green, 2001). This index of body condition may be related to fitness, as we found a relationship between it and chick survival after fledging (J. A. Amat et al., unpublished), and also a relationship between such an index and the dispersal capabilities of individual chicks following independence from parental care has been reported (Barbraud et al., 2003).

From flamingo chicks that were ringed in 1998-2001, we collected between 05:00 and 06:00 h (GMT) $1 \mathrm{~mL}$ of blood from the brachial or jugular veins in heparinized tubes. Depending on year, the number of samples collected varied 94-125. The tubes were kept at $4{ }^{\circ} \mathrm{C}$ until transportation to a field station where the blood samples were centrifuged ( $5 \mathrm{~min}$ at $5000 \mathrm{rpm}$, corresponding to a relative centrifugal force of 1844.7) to separate the plasma, which was stored in cryovials at $-80{ }^{\circ} \mathrm{C}$ until analyses. The separation of plasma was done less than $5 \mathrm{~h}$ after the birds were bled. The analyses of all blood parameters considered (Table 1) were carried out in a Merck autoanalyzer, model Vitalab Selectra, using a homogenized aliquot of $20 \mu \mathrm{L}$ of plasma for each parameter. Samples were diluted five times for analyses of alkaline phosphatase. Because of insufficient plasma in some samples, it was not always possible to determine all parameters in all samples, so sample sizes may vary.

After being fed by their parents, the chicks store the food in their crops, which are sacklike diverticula that when filled
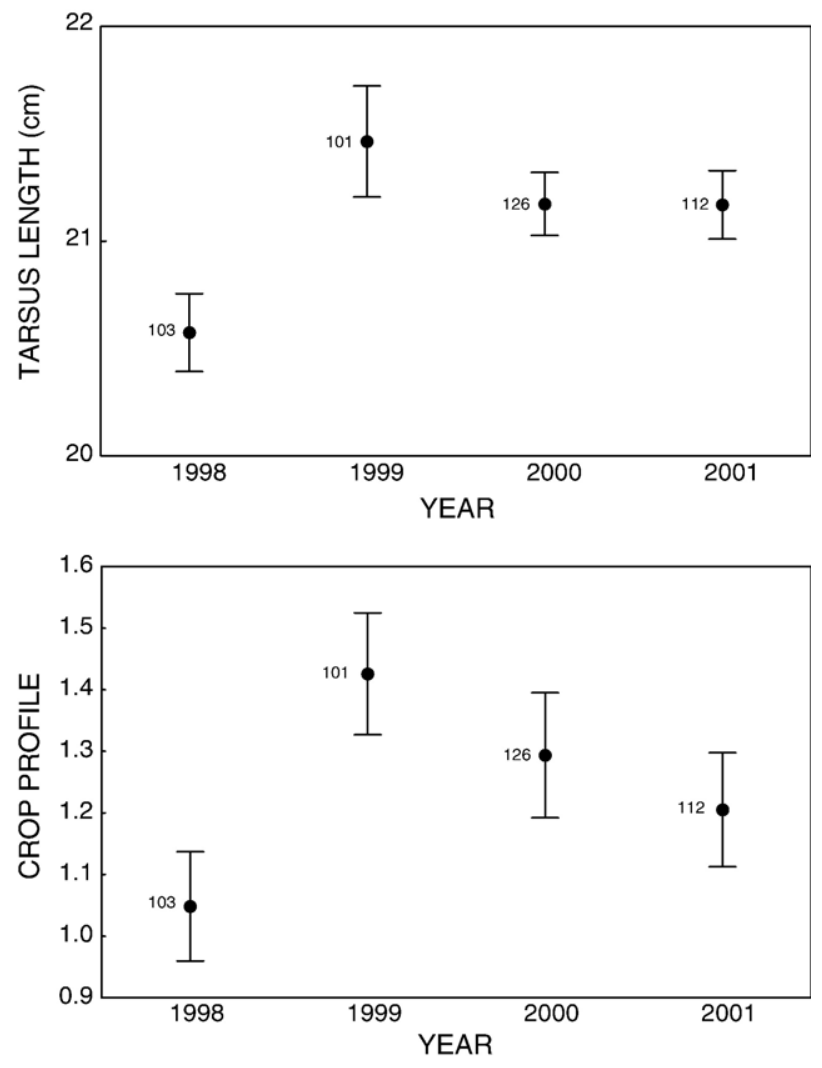

Fig. 1. Annual variations in mean tarsus length ( \pm 1 S.E.) and crop profiles ( \pm 1 S.E.) of greater flamingo chicks at the time of ringing. The crop profiles were allocated to four categories, which varied from concave (crop profile 0 ) to turgid (crop profile 3) depending on the amount of food that chicks had in their crops. Numbers beside dots represent sample sizes.
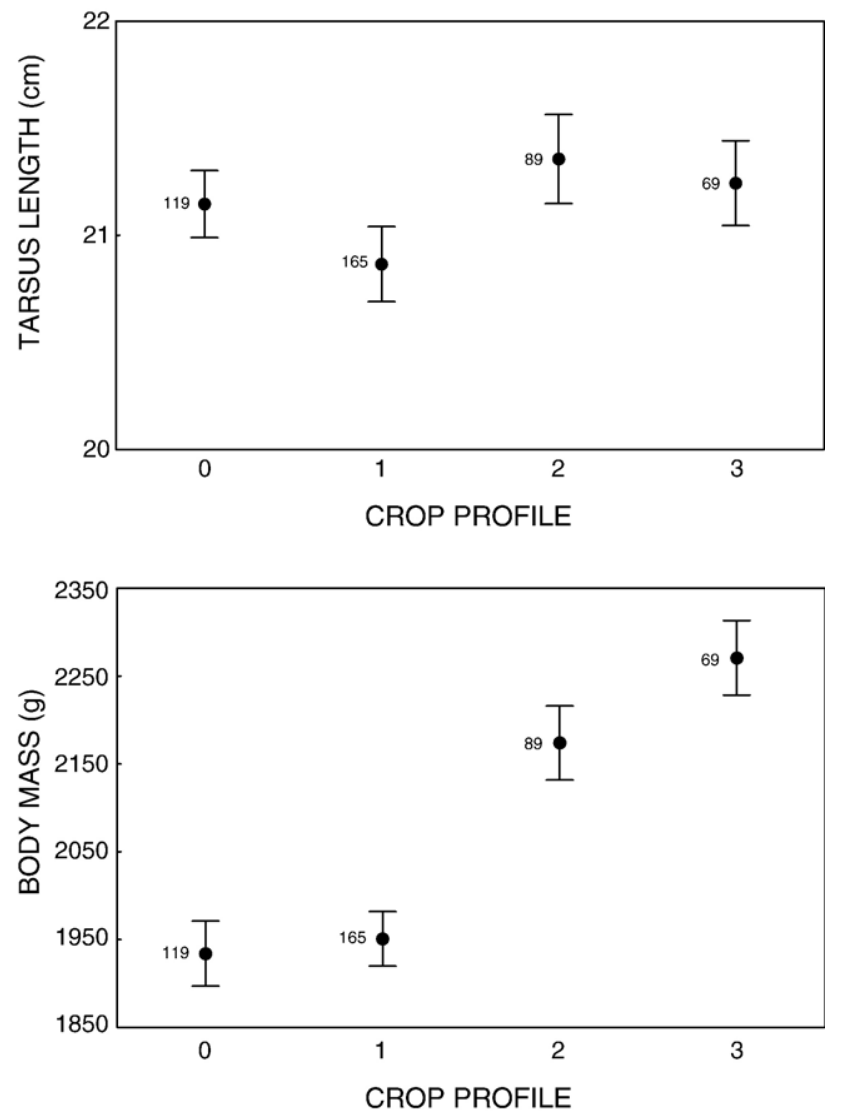

Fig. 2. Variations in mean tarsus length and body mass ( \pm 1 S.E.) of greater flamingo chicks according to crop profile category. Numbers beside dots represent sample sizes.

protrude outward (Ziswiler and Farner, 1972). We recorded the crop profiles of chicks, allocating them to one of the four categories: (0) when the crop profile was slightly concave (i.e., empty), (1) when it was slightly convex, (2) when it was convex, and (3) when it was turgid (J. A. Amat et al., unpubl.). We used the crop profiles as an indication that the chicks were fed the night before the blood samples were collected, since the food is stored in the crops for about 12 h (M. A. Rendón, A. Garrido and J. C. Guerrero, unpublished results).

Because the data were not normally distributed, even after transformations, we used the Kruskal-Wallis one-way analysis of variance (ANOVA) (Siegel and Castellan, 1988) to test differences between years, or according to crop profile category, in plasma chemistry values, as well as annual differences in tarsus lengths. We tested whether there were differences among years in plasma chemistry values using non-parametric analysis of covariance (ANCOVA) (Young and Bowman, 1995), with crop profile as covariate. This ANCOVA is available for $\mathrm{R}$ software at http://lib.stat.cmu.edu/R/CRAN. We used a principal component analysis (PCA) to clarify intraspecific variation in plasma chemistry values. We determined the number of interpretable ordination axes and the significance of loadings using the broken-stick criterion (see Peres-Neto et al., 2003). We used Spearman's rank correlation coefficient (Siegel and Castellan, 1988) to examine relationships between body condition and cholesterol, triglycerides, uric acid, and total 
Table 2

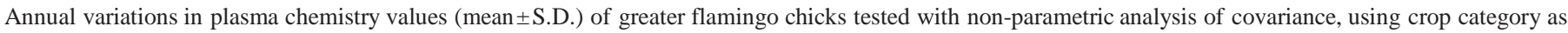
covariate

\begin{tabular}{|c|c|c|c|c|c|}
\hline Parameter & 1998 & 1999 & 2000 & 2001 & $\mathrm{P}$ \\
\hline Glucose (mmol/L) & $11.2 \pm 1.8(99)$ & $11.5 \pm 2.3(93)$ & $11.6 \pm 2.6(114)$ & $11.5 \pm 2.8(105)$ & 0.068 \\
\hline Cholesterol (mmol/L) & $8.5 \pm 2.2(99)$ & $6.7 \pm 2.2(91)$ & $6.6 \pm 1.6(114)$ & $7.4 \pm 1.7$ (107) & 0.003 \\
\hline Triglycerides (mmol/L) & $0.9 \pm 1.0(98)$ & $1.4 \pm 1.6(94)$ & $1.4 \pm 1.9(121)$ & $1.3 \pm 2.0(110)$ & 0.002 \\
\hline Uric acid $(\mu \mathrm{mol} / \mathrm{L})$ & $407.0 \pm 314.3(100)$ & $537.3 \pm 413.9(93)$ & $592.6 \pm 633.0(125)$ & $412.6 \pm 438.7(110)$ & 0.222 \\
\hline Total proteins (g/L) & $36.9 \pm 10.6(101)$ & $44.4 \pm 14.0(93)$ & $51.7 \pm 36.2(123)$ & $44.8 \pm 28.9(112)$ & b0.001 \\
\hline Alkaline phosphatase (U/L) & $1343.0 \pm 434.1(97)$ & $1145.0 \pm 438.8(88)$ & $1194.0 \pm 854.9(124)$ & $1097.7 \pm 326.6(111)$ & 0.304 \\
\hline Calcium (mmol/L) & $2.7 \pm 0.5(95)$ & $2.8 \pm 0.7(83)$ & $3.6 \pm 2.6(108)$ & $3.3 \pm 1.8(104)$ & b0.001 \\
\hline Phosphorus (mmol/L) & $1.9 \pm 0.5(91)$ & $2.1 \pm 0.7(80)$ & $2.2 \pm 1.1(104)$ & $2.0 \pm 0.9(100)$ & b 0.001 \\
\hline Magnesium (mmol/L) & $0.6 \pm 0.2(95)$ & $0.7 \pm 0.4(80)$ & $0.7 \pm 0.3(104)$ & $0.6 \pm 0.2(99)$ & b 0.001 \\
\hline
\end{tabular}

The crop profiles were allocated to four categories depending on their shape. Sample sizes are in parentheses.

proteins. We chose these parameters because they are frequently used to assess the body condition of individuals (see above).

\section{Results}

\subsection{Variations in plasma chemistry}

There were annual differences in the size of flamingo chicks at ringing. Chicks ringed in 1998 were smaller than in the other years $(\mathrm{H}=14.59$, $\mathrm{df}=3, \mathrm{P}=0.002$, Fig. 1$)$. The average scores of the crop profiles were also smaller in 1998 than in the other years, although the differences were statistically non-significant $(\mathrm{H}=7.08$, $\mathrm{df}=3, \mathrm{P}=0.069$, Fig. 1). The percentage of chicks with their crops empty varied annually 20-31\%. There were no differences in the size of chicks according to their crop profile categories (for tarsus length: Kruskal-Wallis ANOVA, $H=2.69$, $\mathrm{df}=3, \mathrm{P}=0.443$, Fig. 2). However, there were significant differences in body masses according to crop profiles $(\mathrm{H}=45.83$, df $=3$, $\mathrm{P}$ b 0.001 , Fig. 2). Differences in the body masses between chicks with crop profiles 0 and 3 indicated that the maximum mass of food received by chicks from their parents was on average $336 \mathrm{~g}$ (Fig. 2).

The concentrations of all plasma parameters analyzed, except cholesterol and alkaline phosphatase, increased with crop profile category (Table 1). Because of the effects of fasting on plasma chemistry values of most parameters, in subsequent

Table 3

Results from principal component analysis of plasma chemistry parameters of greater flamingo chicks

\begin{tabular}{lcccc}
\hline Parameter & PC1 & PC2 & \multicolumn{1}{l}{ PC3 } & \multicolumn{1}{l}{ PC4 } \\
\hline Glucose & 0.599 & 0.232 & 0.188 & -0.646 \\
Cholesterol & 0.052 & 0.762 & -0.597 & -0.111 \\
Triglycerides & 0.907 & 0.005 & -0.065 & 0.160 \\
Uric acid & 0.898 & -0.084 & 0.039 & 0.232 \\
Total proteins & 0.945 & -0.013 & 0.041 & 0.010 \\
Alkaline phosphatase & -0.047 & 0.724 & 0.629 & 0.276 \\
Calcium & 0.890 & -0.052 & 0.011 & -0.038 \\
Phosphorus & 0.797 & -0.101 & 0.136 & -0.195 \\
Magnesium & 0.689 & 0.095 & -0.267 & 0.338 \\
\% variance explained & 53.20 & 13.20 & 9.84 & 8.22
\end{tabular}

Values for every blood parameter show loadings of the first four principal component axes. Significant loadings are in bold. The significance of loadings was assessed following the brocken-stick criterion (see Peres-Neto et al., 2003). statistical analyses we controlled for crop profile category. After controlling for the effects of crop profile, we found annual differences in cholesterol, triglycerides, total proteins, alkaline phosphatase, calcium, phosphorus and magnesium (Table 2).

The first four principal axes of a principal component analysis on blood chemistry values explained $84.5 \%$ of the variance (Table 3). The first principal axis (PC1) was positively associated with glucose, triglycerides, uric acid, total proteins, calcium, phosphorus and magnesium (Table 3). PC2 was positively associated with cholesterol and alkaline phosphatase. PC3 was positively associated with alkaline phosphatase and
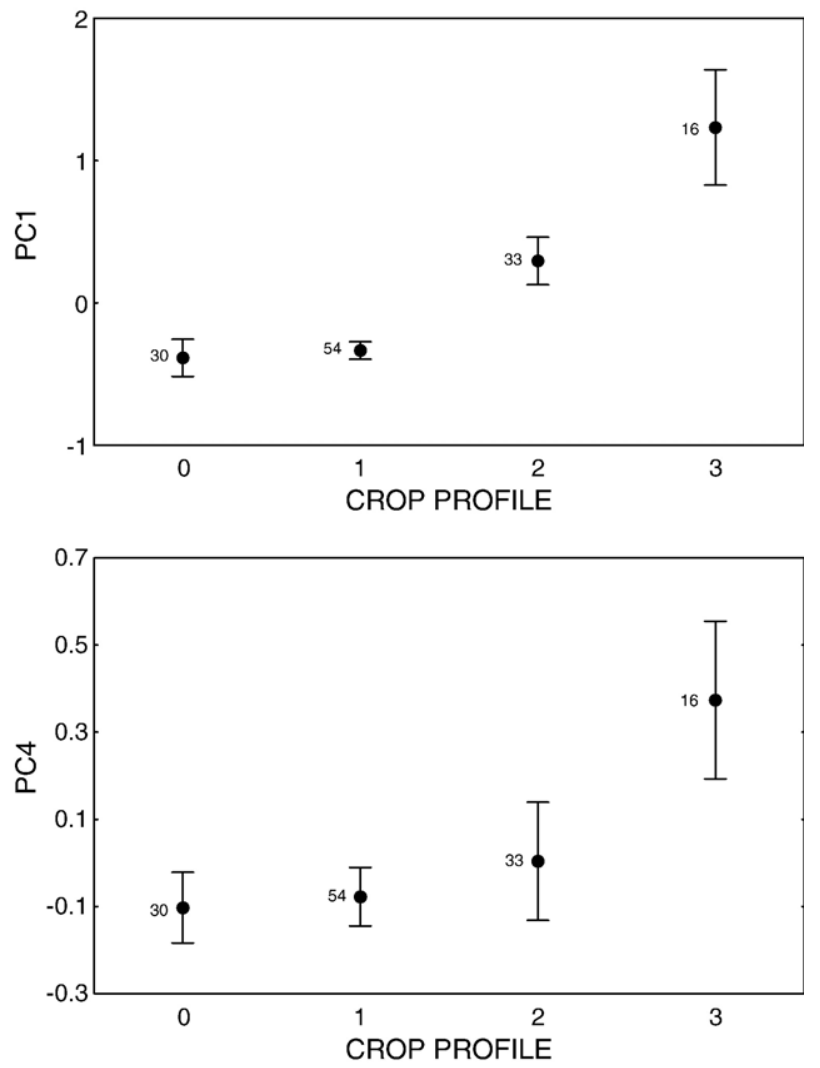

Fig. 3. Variations in average loading factors on the first and fourth principal axes ( \pm 1 S.E.) according to crop profile category of greater flamingo chicks. The loading factors resulted from a principal component analysis of plasma chemistry parameters (see Table 1). Numbers beside dots represent sample sizes. 
negatively with cholesterol. PC4 was negatively associated with glucose.

Of the scores of the first four PC axes, those of PC1 $(\mathrm{H}=118.78, \mathrm{df}=3, \mathrm{P}$ b 0.001, Fig. 3$)$ and PC4 $(\mathrm{H}=9.61, \mathrm{df}=3$, $\mathrm{P}=0.022$, Fig. 3 ) were affected by the crop profile category of chicks, but not those of PC2 $(\mathrm{H}=4.75, \mathrm{df}=3, \mathrm{P}=0.191)$ and PC3 $(H=2.34, d f=3, P=0.505)$. There were interannual variations in PC1 when crop profile category was controlled for in a non-parametric ANCOVA (P b 0.001), as well as in PC2 ( $\mathrm{P}$ b 0.001), but not in PC3 $(\mathrm{P}=0.051)$ nor in PC4 $(\mathrm{P}=0.065)$.

\subsection{Plasma chemistry and body condition}

Because of the effects of fasting on plasma chemistry, we performed separated analyses of data depending on whether the chicks had been fed the night before they were bled (crop profile categories 1-3) or had not been fed (crop profile category 0). For chicks that had not been fed, there were significant relationships between body condition and both cholesterol $\left(r_{s}=-0.36, n=103\right.$, $\mathrm{P} \mathrm{b} 0.001)$ and total proteins $\left(\mathrm{r}_{\mathrm{s}}=0.47, \mathrm{n}=112, \mathrm{P} \mathrm{b} 0.001\right)$, but not between body condition and both triglycerides $\left(r_{s}=-0.08\right.$, $\mathrm{n}=111, \mathrm{P}=0.393)$ and uric acid $\left(\mathrm{r}_{\mathrm{s}}=-0.06, \mathrm{n}=114, \mathrm{P}=0.510\right)$. The levels of these metabolites were not affected by chick size (Spearman's rank correlations, all Ps N 0.05), except protein level $\left(r_{s}=0.19, n=114, P=0.038\right)$. However, when we excluded chicks sampled in 1998, this last relationship was no longer significant $\left(r_{s}=0.07, n=84, P=0.511\right)$.

For chicks that had been fed, there were significant relationships between body condition and cholesterol $\left(r_{\mathrm{s}}=-0.36\right.$, $\mathrm{n}=297, \mathrm{P} \mathrm{b} 0.001)$, total proteins $\left(\mathrm{r}_{\mathrm{s}}=0.46, \mathrm{n}=305, \mathrm{P}\right.$ b 0.001), uric acid $\left(r_{s}=0.40, n=302, P b 0.001\right)$, and triglycerides $\left(r_{s}=0.34, n=300, P b 0.001\right)$. As for chicks with their crops empty, the levels of these metabolites in chicks that had been fed were not affected by chick size (Spearman's rank correlations, all Ps N0.05), except in the case of protein level $\left(r_{s}=0.18\right.$, $\mathrm{n}=315, \mathrm{P}=0.037$ ). However, when we excluded chicks sampled in 1998, this last relationship was no longer significant $\left(\mathrm{r}_{\mathrm{s}}=\right.$ $-0.07, n=244, P=0.753$ ). Therefore, the relationship between plasma proteins and tarsus length was due to an effect of year rather than to an effect of chick size per se.

\section{Discussion}

\subsection{Variations in plasma chemistry}

Our results provide evidence that greater flamingo chicks experience fasting periods. First, about one third of the chicks had their crops empty at the time of ringing every year. This evidence, however, is not conclusive because it may be that chicks with the crop empty had been fed very early in the night, and when we captured them in the next morning they had emptied their crops. Second, and most important, plasma chemistry indicated that some chicks were fasting when they were bled, as suggested by the results of a PCA on plasma chemistry of chicks. PC1 was mainly affected by chicks that had been fed the night before they were captured, as it mainly correlated with biochemical parameters that show an increase in the plasma after a recent feeding (total proteins, uric acid, and triglycerides), and with ions that are transported with proteins (e.g., calcium) (Robbins 1983). In fact, PC1 was affected by crop profile category. PC2 was affected by chicks that were likely fasting, as suggested by its positive association with cholesterol and alkaline phosphatase. Variations in blood levels of this enzyme may indicate rapid responses to food availability (see Viñuela and Ferrer, 1997). The positive association of alkaline phosphatase with PC3 indicates that this PC axis would be associated with differences in skeletal ossification among chicks (Dobado-Berrios and Ferrer, 1997; Tilgar et al., 2004), and not with fasting as in PC2, because the association of PC3 with cholesterol was negative. Alkaline phosphatase is essential for the growth and mineralization of bones. Finally, PC4 was likely affected by chicks in a more advanced state of fasting than those associated with PC2, as suggested by its association with glucose levels. PC4 was affected, as PC1, by crop profile of chicks. The fact that uric acid levels loaded positively on PC1 together with other metabolites that increase after a recent feeding (see above) indicates high protein turnover. Indeed, the digestion of dietary protein is very rapid (Griminger and Scanes, 1986), suggesting that the high plasma uric acid levels recorded in recently fed flamingo chicks would not be the result of body protein catabolism during fasting periods experienced just before feeding (see Ferrer and Dobado-Berrios, 1998). Therefore, because uric acid levels did not load positively on any PC axis together with glucose, our results suggest that there was no protein catabolism due to fasting (see Jenni-Eiermann and Jenni, 1994), likely because most flamingo chicks did not experience severe fasting.

The annual variations in PC1 suggest that chicks received food of different quality in different years, whereas annual variations in PC2 indicate that chicks were not fed with the same frequency every year. This may be due to the fact that the chicks were not of similar age when they were ringed every year. Apparently, some late-born flamingo chicks are deserted by one of their parents before they fledge (Rendón-Martos et al., 2000), and this may explain why they are fed less frequently (J. A. Amat et al., unpubl.). Indeed, chicks in 1998 were smaller and had higher levels of cholesterol than chicks in the other years, suggesting that the time elapsing between feedings was longer in 1998 than in the other years (see below).

A comparison of our results with those of previous studies on flamingos is difficult because most previous studies have been conducted in captivity (see Introduction). The study of Puerta et al. (1992) concluded that variations in plasma chemistry of greater flamingos were mainly affected by captivity (i.e., by the type of food supplied, see also Norambuena and Parada, 2005), rather than by age-related changes. Our results on flamingo chicks suggest that the study of plasma chemistry of species that use habitats that experience a high degree of environmental variability should encompass contrasting conditions. In this way, the effects of temporal variations, and even those of habitat-related social factors (e.g., intraspecific competitive interactions due to variations in density of individuals at foraging sites; see Alonso-Alvarez, 2005) on the nutritional condition of individuals should be more apparent. 


\subsection{Plasma chemistry, body condition and frequency of feedings}

Several studies have proposed that some plasma metabolites, such as total proteins and some lipids, may be used to assess the body condition of individuals, as they may give an indication on their physiological state (Jenni-Eiermann and Jenni, 1994; Ots et al., 1998; Williams et al., 1999; Guglielmo et al., 2002; Artacho et al., 2007). The studies relating plasma triglycerides to body mass changes have reported conflicting results (see Seaman et al., 2005). These inconsistencies may be due in part to the fact that some of such studies did not correct for the mass of food that birds could have had in their guts when body masses were recorded. As we have shown, there was a positive relationship between plasma triglyceride levels and crop profiles. Thus, although this may indicate a rapid resorptive nutritional state, our results also indicate that the mass of food in the guts of individuals should be controlled for when relating body mass changes to plasma metabolite levels. In fact, for greater flamingo chicks that were fasting (crop profile category 0), there was no relationship between body condition and plasma triglycerides.

We also found that individuals with higher levels of proteins in plasma were in better condition, both for chicks that received a recent feeding and for those that were fasting. Other studies have also found that total proteins in plasma is a conditionrelated variable (Dawson and Bortolotti, 1997; Ots et al., 1998; Totzke et al., 1999; but see Quillfeldt et al., 2004), although as indicated by Dawson and Bortolotti (1997) and Villegas et al. (2002), the level of proteins in the plasma may be confounded by other factors. Therefore, we concur with Dawson and Bortolotti (1997) and Villegas et al. (2002) in that total proteins should not be considered as a condition index until further work is performed to ascertain how total plasma protein levels vary with body condition when other factors known to affect such levels are controlled for. However, as in cases of malnutrition there is a decrease in total plasma protein levels, this blood parameter may be useful to compare the nutritional status of individuals among localities (Ots et al., 1998) or between years (Hollmén et al., 2001; this study).

Cholesterol concentration in plasma was related to body condition independently of whether the flamingo chicks had received a recent feeding or were fasting. Weimerskirch et al. (2000) found that the longer and more variable the duration of fasting intervals, the lower the body condition of chicks. Although in some bird species cholesterol levels may increase after feeding or remain unaffected by starvation (Ferrer and Dobado-Berrios, 1998), in other species they have been found to increase during fasting (Jeffrey et al., 1985; García-Rodríguez et al., 1987). In addition, cholesterol concentration has proven useful to reveal trends in body mass changes (Alonso-Alvarez et al., 2002). All this indicates that plasma concentrations of cholesterol may be affected by environmental conditions experienced by individuals over several days. We obtained crop size scores as a measure of the frequency with which the chicks were fed. It may be that this procedure may hardly be used as a reliable information on parental provisioning rates over the whole period of parental dependence (80-90 days) because the data were obtained during a single day every season. In the case of greater flamingo chicks, there was a negative relationship between average annual plasma cholesterol levels (Table 1) and average annual crop profiles (Fig. 1), although due to small sample size it was non-significant $\left(r_{s}=-0.80, n=4, P=0.200\right)$. This may indicate that the crop profiles of chicks could give an idea of the frequency with which the chicks were being fed every season. High plasma concentrations of cholesterol in fasting individuals may result from dehydration (see Introduction), which may be due to the role of cholesterol in the protection against liposome degradation during dehydration episodes (Samuni et al., 2000).

\section{Acknowledgements}

We thank all the people that participated in the ringing drives of flamingo chicks at Fuente de Piedra during 1998-2001. We also thank veterinarians from Grupo VESAL (Veterinarios de Especies Silvestres de Andalucía y Levante) for their help in the extraction of blood samples. Macarena Castro, David Cuenca, Maribel Gil, M. Carmen León, Sora Marín, José A. Masero, Elena Moreno, Gonzalo Olías, Ana B. Rojas and Margarita Siquier assisted to separate the plasma. Juan Miguel Mancera assisted with the analyses of plasma. Financial support was obtained through a collaborative agreement between Consejería de Medio Ambiente (Junta de Andalucía) and Consejo Superior de Investigaciones Científicas. During manuscript preparation we were funded by Dirección General de Investigación with EU-ERDF support (research grants BOS2002-04695 and CGL2005-01136/BOS). We thank Carlos Alonso-Álvarez, Miguel Ferrer, Auxiliadora Villegas, and an anonymous referee for comments on previous versions.

\section{References}

Alonso-Alvarez, C., 2005. Age-dependent changes in plasma biochemistry of yellow-legged gulls (Larus cachinnans). Comp. Biochem. Physiol. A 140, 512-518.

Alonso-Alvarez, C., Ferrer, M., 2001. A biochemical study of fasting, subfeeding, and recovery processes in yellow-legged gulls. Physiol. Biochem. Zool. 74, 703-713.

Alonso-Alvarez, C., Ferrer, M., Velando, A., 2002. The plasmatic index of body condition in yellow-legged gulls Larus cachinnans: a food-controlled experiment. Ibis 144, 147-149.

Alonso-Alvarez, C., Ferrer, M., Viñuela, J., Amat, J.A., 2003. Plasma chemistry of the chinstrap penguin Pygoscelis antarctica during fasting periods: a case of poor adaptation to food deprivation? Polar Biol. 26, 14-19.

Amat, J.A., Rendón, M.A., Rendón-Martos, M., Garrido, A., Ramírez, J.M., 2005. Ranging behaviour of greater flamingos during the breeding and postbreeding periods: linking connectivity to biological processes. Biol. Conserv. 125, 183-192.

Artacho, P., Soto-Gamboa, M., Verdugo, C., Nespolo, R.F., 2007. Blood chemistry reveals malnutrition in black-necked swans (Cygnus melanocoryphus) living in a conservation priority area. Comp. Biochem. Physiol. A 146, 283-290.

Baldassarre, G.A., Arengo, F., 2000. A review of the ecology and conservation of Caribbean flamingos in Yucatán, Mexico. Waterbirds 23, 70-79 (Spec. Publ. 1).

Barbraud, C., Johnson, A.R., Bertault, G., 2003. Phenotypic correlates of postfledging dispersal in a population of greater flamingos: the importance of body condition. J. Anim. Ecol. 72, 246-257.

Booth, A.M., Minot, E.O., Fordham, R.A., Imber, M.J., 2000. Co-ordinated provisioning in the little shearwater Puffinus assimilis haurakiensis: a 
previously undescribed foraging strategy in the Procellariidae. Ibis 142, 144-146.

Brown, M.E., 1996. Assessing body condition in birds. In: Nolan Jr., V., Ketterson, E.D. (Eds.), Current Ornithology, vol. 13. Plenum Press, New York, pp. 66-135.

Campbell, N.R.C., Wickert, W., Magner, P., Shumak, S.L., 1994. Dehydration during fasting increases serum-lipids and lipoproteins. Clin. Invest. Med. 17, 570-576.

Chaurand, T., Weimerskirch, H., 1994. The regular alternation of short and long foraging trips in the blue petrel Halobaena caerulea: a previously undescribed strategy of food provisioning in a pelagic seabird. J. Anim. Ecol. 63, 275-282.

Dawson, R.D., Bortolotti, G.R., 1997. Total plasma protein level as an indicator of condition in wild American kestrels (Falco sparverius). Can. J. Zool. 75, 680-686.

Dobado-Berrios, P.M., Ferrer, M., 1997. Age-related changes in plasma alkaline phosphatase and inorganic phosphorus, and late ossification of the cranial roof in the Spanish imperial eagle (Aquila adalberti C. L. Brehm, 1861). Physiol. Zool. 70, 421-427.

Driver, E.A., 1981. Hematological and blood chemistry values of mallard, Anas p. platyrhynchos, drakes before, during and after remige moult. J. Wildl. Dis. 17, 413-421.

Ferrer, M., Dobado-Berrios, P., 1998. Factors affecting plasma chemistry values of Spanish imperial eagle (Aquila adalberti). Comp. Biochem. Physiol. A 120, 209-217.

García-Rodríguez, T., Ferrer, M., Carrillo, J.C., Castroviejo, J., 1987. Metabolic responses of Buteo buteo to long-term fasting and refeeding. Comp. Biochem. Physiol. A 87, 381-386.

Green, A.J., 2001. Mass/length residuals: measures of body condition or generators of spurious results? Ecology 82, 1473-1483.

Griminger, P., Scanes, C.G., 1986. Protein metabolism, In: Sturkie, P.D. (Ed.), Avian Physiology, fourth edition. Springer-Verlag, New York, pp. 326-344.

Giuglielmo, C.G., O'Hara, P.H., Williams, T.D., 2002. Extrinsic and intrinsic sources of variation in plasma lipid metabolites of free-living western sandpipers (Calidris mauri). Auk 119, 437-445.

Hamer, K.C., Nicholson, L.W., Hill, J.K., Wooller, R.D., Bradley, J.S., 1997. Nestling obesity in procellariiform seabirds: temporal and stochastic variation in provisioning and growth of short-tailed shearwaters Puffinus tenuirostris. Oecologia 112, 4-11.

Hawkey, C., Hart, M.G., Samour, H.J., Knight, J.A., Hutton, R.E., 1984. Haematological findings in healthy and sick captive rosy flamingos (Phoenicopterus ruber ruber). Avian Pathol. 13, 163-172.

Hawkey, C., Hart, M.G., Samour, H.J., 1985. Normal and clinical haematology of greater and lesser flamingos (Phoenicopterus ruber roseus and Phoeniconaias minor). Avian Pathol. 14, 537-541.

Hollmén, T., Franson, J.C., Hario, M., Sankari, S., Kilpi, M., Lindström, K., 2001. Use of serum biochemistry to evaluate nutritional status and health of incubating common eiders (Somateria mollissima) in Finland. Physiol. Biochem. Zool. 74, 333-342.

Jeffrey, D.A., Peakall, D.B., Miller, D.S., Herzberg, G.R., 1985. Blood chemistry changes in food deprived herring gulls. Comp. Biochem. Physiol. A 81, 911-913.

Jenni-Eiermann, S., Jenni, L., 1994. Plasma metabolite levels predict individual body mass changes in a small long-distance migrant, the garden warbler. Auk 112, 888-899.

Jenni-Eiermann, S., Jenni, L., 1996. Metabolic differences between the postbreeding, moulting and migratory periods in feeding and fasting passerine birds. Funct. Ecol. 10, 62-72

Le Maho, Y., Vu Van Kha, H., Koubi, H., Dewasmes, G., Girard, J., Ferré, P., Cagnard, M., 1981. Body composition, energy expenditure, and plasma metabolites in long-term fasting geese. Am. J. Physiol. 241, E342-E354.

Mostaghni, K., Badiei, K., Nili, H., Fazeli, A., 2005. Haematological and biochemical parameters and the serum concentrations of phosphorus, lead, cadmium and cromium in flamingo (Phoenicopterus ruber) and blackheaded gull (Larus ridibundus) in Iran. Comp. Clin. Pathol. 14, 146-148.

Norambuena, M.C., Parada, M., 2005. Serum biochemistry in Andean flamingos (Phoenicoparrus andinus): natural versus artificial diet. J. Zoo Wildl. Med. 36, 434-439.
Ots, I., Murumägi, A., Hõrak, P., 1998. Haematological health state indices of reproducing great tits: methodology and sources of natural variation. Funct. Ecol. 12, 700-707.

Peinado, V., Polo, F.J., Viscor, G., Palomeque, J., 1992. Haematology and blood chemistry values for several flamingo species. Avian Pathol. 21, 55-64.

Peres-Neto, P.R., Jackson, D.A., Somers, K.M., 2003. Giving meaningful interpretation to ordination axes: assessing loading significance in principal component analysis. Ecology 84, 2347-2363.

Perry, M.C., Obrecht III, H.H., Williams, B.K., Kuenzel, W.J., 1986. Blood chemistry and hematocrit of captive and wild canvasbacks. J. Wildl. Manage. 50, 435-441.

Puerta, M.L., García del Campo, A.L., Abelenda, M., Fernandez, A., Huecas, V., Nava, M.P., 1992. Hematological trends in flamingos, Phoenicopterus ruber. Comp. Biochem. Physiol. A 102, 683-686.

Puerta, M.L., Huecas, V., García del Campo, A.L., 1989. Hematology and blood chemistry of the Chilean flamingo. Comp. Biochem. Physiol. A 94, 623-625.

Pyrovetsi, M., 1989. Foraging trips of white pelicans (Pelecanus onocrotalus) breeding on lake Mikri Prespa, Greece. Colon. Waterbirds 12, 43-50.

Quillfeldt, P., Masello, J.F., Möstl, E., 2004. Blood chemistry in relation to nutrition and ectoparasite load in Wilson's storm-petrels Oceanites oceanicus. Polar Biol. 27, 168-176.

Rendón, M.A., Garrido, A., Ramírez, J.M., Rendón-Martos, M., Amat, J.A., 2001. Despotic establishment of breeding colonies of greater flamingos, Phoenicopterus ruber, in southern Spain. Behav. Ecol. Sociobiol. 50, 55-60.

Rendón-Martos, M., 1996. La laguna de Fuente de Piedra en la dinámica de la población de Flamencos (Phoenicopterus ruber roseus) del Mediterráneo occidental. Ph. D. thesis, University of Málaga.

Rendón-Martos, M., Johnson, A.R., 1996. Management of nesting sites for greater flamingos. Colon. Waterbirds 19, 167-183 (Spec. Publ. 1).

Rendón-Martos, M., Vargas, J.M., Rendón, M.A., Garrido, A., Ramírez, J.M., 2000. Nocturnal movements of breeding Greater Flamingos in southern Spain. Waterbirds 23, 9-19 (Spec. Publ. 1).

Richdale, R.E., 1963. Biology of the sooty shearwater Puffinus griseus. Proc. Zool. R. Soc. Lond. 141, 1-117.

Robbins, C.T., 1983. Wildlife Feeding and Nutrition. Academic Press, New York.

Robin, J.-P., Cherel, Y., Girard, H., Géloen, A., Le Maho, Y., 1987. Uric acid and urea in relation to protein catabolism in long-term fasting geese. J. Comp. Physiol. B 157, 491-499.

Robin, J.-P., Frain, M., Sardet, C., Groscolas, R., LeMaho, Y., 1988. Protein and lipid utilization during long-term fasting in emperor penguins. Am. J. Physiol. 254, R61-R68.

Rodríguez-Pérez, H., Green, A.J., 2006. Waterbird impacts on wigeon grass Ruppia maritima in a Mediterranean wetland: comparing bird groups and seasonal effects. Oikos 112, 525-534.

Samuni, A.M., Lipman, A., Barenholz, Y., 2000. Damage to liposomal lipids: protection by antioxidants and cholesterol-mediated dehydration. Chem. Phys. Lipids 105, 121-134.

Seaman, D.A., Guglielmo, C.G., Williams, T.D., 2005. Effects of physiological state, mass change, and diet on plasma metabolite profiles in the western sandpiper Calidris mauri. J. Exp. Biol. 208, 761-769.

Siegel, S., Castellan Jr., N.J., 1988. Nonparametric Statistics for the Behavioral Siences, 2nd Ed. McGraw-Hill, New York.

Tilgar, V., Ots, I., Mänd, R., 2004. Bone alkaline phosphatase as a sensitive indicator of skeletal development in birds: a study of the great tit nestlings. Physiol. Biochem. Zool. 77, 530-535.

Totzke, U., Fenske, M., Hüppop, O., Raabe, H., Schach, N., 1999. The influence of fasting on blood and plasma composition of herring gulls (Larus argentatus). Physiol. Biochem. Zool. 72, 426-437.

Villegas, A., Sánchez, J.M., Costillo, E., Corbacho, C., 2002. Blood chemistry and haematocrit of the black vulture (Aegypius monachus). Comp. Biochem. Physiol. A 132, 489-497.

Viñuela, J., Ferrer, M., 1997. Regulation of growth in red kites and imperial eagles. Wilson Bull. 109, 92-101.

Weimerskirch, H., 1998. How can a pelagic seabird provision its chick when relying on a distant food source? Cyclic attendance at the colony, foraging 
decision and body condition in sooty shrearwaters. J. Anim. Ecol. 67, 99-109.

Weimerskirch, H., Barbraud, C., Lys, P., 2000. Sex differences in parental investment in wandering albatrosses: fitness consequences. Ecology 81, 309-318.

Williams, T.D., Guglielmo, C.G., Egeler, O., Martyniuk, C.J., 1999. Plasma lipid metabolites provide information on mass change over several days in captive western sandpipers. Auk 116, 994-1000.
Young, S.G., Bowman, A.W., 1995. Nonparametric analysis of covariance. Biometrics 51, 920-931.

Ziswiler, V., Farner, D.S., 1972. Digestion and the digestive system. In: Farner, D.S., King, J.R. (Eds.), Avian Biology, vol. II. Academic Press, New York, pp. 343-430. 